\title{
Migration, Xenophobia and \\ Resistance to Xenophobia, and \\ Socio-economic Exclusion in the Aftermath of South African Rainbowism
}

\author{
Buhle Mpofu
}

\begin{abstract}
Recent statements by South African political leaders emphasize differences between citizens rather than highlight similarities. Such politics of exclusion and populist politics is a far cry from the ANC's Freedom Charter statement that 'South Africa belongs to all who live in it', and the designation given to South Africa with the advent of democracy in 1994, as the rainbow nation. This article reflects on the position of migrants in South Africa over the past 25 years. This article highlights the different articulations of South African Rainbowism through interrogating the position of migrants in some of the economic development policies during this period. The article shows that from Mandela's Reconstruction Economic Development (RDP), Mbeki's Growth, Employment and Redistribution (GEAR) and more recently, Zuma's Radical Economic Transformation (RET), the opportunities and recognition of migrants has remained elusive. In addition to the policy shifts, this article reflects on the level of representation and inclusiveness promoted in South African party-political manifestos. Finally, this paper employs the notion of marginality as described by Messiou (2012), and Bell Hooks' (1990) concept of 'marginality as a site of resistance' and opportunity. The rationale here is that, despite the constitutional provisions that 'South Africa belongs to all who live in it, united in our diversity', the socio-economic privileging of its citizens over migrants impede on the realisation of a just post-apartheid society.
\end{abstract}


Keywords: Marginality, Xenophobia, South Africa, Migration, Socio-economic Transformation

\section{Introduction}

Globally, increased migration often results in restrictive regulatory responses to migration flows, especially in Europe where increasingly, refugees and asylum seekers fleeing wars are framed as a 'security threat' and which criminalises any act of seeking safety. In June 2018, for example, the world witnessed a 'cruel stand-off' (CNBC 2018) on the Mediterranean when the governments of Italy and Malta refused entry of a vessel with 630 migrants and asylum seekers. This position restricted the ability of these migrants from accessing care from humanitarian organizations. Equally disturbing was the European Union (EU)'s deal with the government of Turkey through which the EU provided Turkey with financial compensation to block asylum seekers and migrants from entering Europe. Similar developments are playing themselves out subtly within the South African context.

This article primarily provides an overview of the South African migrants' experience and highlights policy shifts with respect to public discourses from the 'rainbow nation', with the advent of democracy to recently, an almost institutionalised form of xenophobia. By reflecting on the lived experiences of African migrants in South Africa, the article notes that while initially, Mandela's rainbow nation and Mbeki's redevelopment programs were inclusive and accommodated foreign migrants in addressing the socio-economic inequalities of the past, the last ten years has witnessed an ideological shift which purports the idea of the migrant as "the other" and has changed the mood from inclusion to marginalization. It is in this context that this article seeks to examine South African rainbowism through reflecting on the narratives of migrant's resilience because 'to be in the margin is to be part of the whole but outside the main body, living on the edge' (Hooks 1990).

\section{South Africa's Rainbow Nation - An Elusive Dream?}

The ideal of a rainbow nation was a vision of Nelson Mandela and Desmond Tutu who opened up a way for a society that would bring a fresh meaning to the 
celebration of human life in all its individual uniqueness and thus demonstrate a key aspect of 'aesthetic existence' (Du Toit 2006: 51). Working towards the ideal Rainbow nation has not been without its challenges. Anthea Jeffrey of the South African Institute of Race Relations (SAIRR) in her book 'Chasing the Rainbow: South Africa's Move from Mandela to Zuma', traces two decades into South Africa's democracy by reflecting on ten crucial policy areas termed the 'ten pillars of democracy' ranging from individual rights and racial goodwill to growth-focused policies, free enterprise, and good citizenship. By analysing the government's performance through these pillars, the book reveals how the country is struggling to fulfil the hopes that were raised at the dawn of what was envisaged as a 'rainbow nation'. From 1994 under the leadership of Mandela, the South African government prioritised focus on job creation and alleviating poverty, through provision of social grants and free houses under the Reconstruction and Development Programme. Mandela's Rainbow Nation was inclusive and sought to deal with poverty and socio-economic inequality through the inclusive economic policies, with little or no politically motivated scapegoating of foreign migrants.

From 1999 to 2008 reconstruction and development continued under the Presidency of Thabo Mbeki, even though his tenure was marked by a number of issues including; being tolerant of incompetent ministers; and failure of his administration to condemn xenophobia openly, as mapped by Barney Pityana in his recent book Building Blocks Towards An African Century (2018). Despite criticisms of these issues, Mbeki was credited for the development and implementation of the Growth, Employment and Redistribution (GEAR) program as a micro economic strategy for South Africa, although some considered it a neoliberal framework which fuelled anger and created divisions within the movement (Gelb 2006). Although contested, policies of affirmative action and Black Economic Empowerment (BEE) emerged as key drivers to build a black middle class. For Moeletsi Mbeki, BEE 'strikes a fatal blow against black entrepreneurship by creating a small class of unproductive but wealthy black crony capitalists made up of ANC politicians' (2011) which led him to conclude that policies pursued by the South African government do not promote inclusive economic development, because they exclude or marginalise people.

On the $9^{\text {th }}$ of May 2009 Jacob Gedleyihlekisa Zuma ascended to the South African presidency on a wave of popular euphoria and sympathy by voters who were frustrated with declining economic growth, slow transfer of wealth, rising unemployment and poor service delivery. With his endorsement as the 


\section{Buhle Mpofu}

leader of the African National Congress (ANC), came the newer Radical Economic Transformation (RET). This program was born out of the ANC's 53rd National Conference at Mangaung in 2012 where it was resolved that economic transformation and democratic consolidation will be advanced through 'radical' economic transformation. In 2017 the ANC assessed economic conditions locally and globally, then later adopted the policy for implementation. The climate in the country had shifted already, and there were growing protests against poor service delivery and economic exclusion, with increasing violence against African migrants in particular, who are perceived to be 'stealing jobs from South Africans' and eroding the few opportunities available to lcoals (Crush 2013). This ideological shift against foreigners and the change in mood from inclusion to marginalization of migrants in the economic development programs, translated into a kind of popular license tract against African migrants. While during the periods of Mandela and Mbeki, there was no xenophobia, it had now assumed an ideological basis supported by political rhetoric which portrayed migrants as a problem, leaving them marginalised in policy formulation, as well as excluded from economic participation, work, school and health services (Mkhwanazi 2017).

Giving a renewed sense of hope towards reviving the dream of a rainbow nation, President Cyril Matamela Ramaphosa took over as President when unemployment had grown to $27 \%$ and public health care had deteriorated and is seen as incapable of coping with the growing burden of patients (ILO 2018). Ramaphosa emerged as the source of hope and inspiration in the restoration of the dreams and vision of a rainbow nation. To give hope to the nation, he invoked the lyrics of a song by the late struggle and music icon Hugh Masekela called 'Thuma mina' or 'Send $\mathrm{Me}$ ' in a desperate effort to restore confidence in the government and as a call to unite South Africans. He pointed out that 'as South Africans we have to ask ourselves whether we have realised the promise of our nation's birth', and while his speech at that occasion, did not extend a call for renewed collective nation building to foreigners' resident in the country, it very narrowly addressed 'fellow' South Africans as evidenced in the excerpt from his speech below:

In our magnificent diversity, and despite our many differences, the people of this country answered the call of Thuma mina (Send Me). In their multitudes, South Africans asked not what can be done for them, but what they could do for their country. In ways both large and small, 
both public and private, South Africans set about building a better nation (IOL 2018).

Agnes Musonda and Liesbeth Schokaert (2018) in their article, 'South Africa on a perilous path to making criminals of people of the move' noted the subtle moves of the government to stifle migration:

Last year, the Cabinet approved locating the Department of Home Affairs within the security cluster (alongside justice, police, military and correctional services). It repositioned the department towards adopting a new, empowered border management approach and playing a strategic role in South Africa's economic development. Additionally, South Africa's recently adopted white paper on international migration is evidence of a trajectory that will conflate migration legislation and policy with national security and migrants with skills and capital, and shut out unskilled people from the region with more stringent measures, including criminalising the undocumented, who keep entering the country .... In crude terms, it proposes introducing interventions to 'attract international migrants with skills and capital', and shut out unskilled people from the region with more stringent measures (Musonda \& Schockeart 2018).

In what the Musonda and Schockeart (2018) refer to as a callous policy, they argue that the passing of the Border Management Agency Bill by the National Assembly set in motion the creation of a centralised authority with sweeping powers over South Africa's ports of entry, including policing and customs. Based on the comparisons with the developments in Europe, Musonda and Schokaert (2018) conclude that the White Paper paved way towards South Africa's eerie path which is reminiscent of what we have witnessed in Europe and they warn that South Africans now face a challenge to:

stand up to prevent a roll-back of protections that vulnerable people require when they flee persecution and unliveable conditions back home, or witness the institutionalised erosion of humanity and dignity we've seen globally (Musonda \& Schokaert 2018). 


\section{Conceptualising Marginalisation and Marginality}

The preceding section highlighted how the South African government policy has subtly shifted towards marginalising and excluding foreign migrants. This section provides an examination of the concepts of marginality and exclusion in order to reflect on the experience of migration and economic deprivation in South Africa.

The terms marginality, exclusion, rejection and ostracism can be used interchangeably, as attempts to distinguish them has demonstrated that there is no significant difference, given that they all indicate a situation that threatens humans' fundamental need for belonging (Leary 2005). While some literature focuses on socio-economic and political exclusion (Twenge et al. 2001), others have focused on social exclusion. Razer et al. (2013: 152) define social exclusion as a state in which individuals or groups 'lack effective participation in key activities or benefits of the society in which they live' (2013:152). Developing on this argument, Armstrong et al. (2011) and Hansen (2012) also agree that inclusion and exclusion are two interrelated and interdependent processes, although, the latter argues that it is over-simplistic to equate exclusion as being the opposite of inclusion (or vice versa). Rejection is understood by Williams (2007) as a 'declaration that other people do not want to interact any longer' and for him, ostracism implies 'being ignored or excluded, not necessarily with negative signs' (Williams 2007). In view of these debates, this paper understands marginality as:

an involuntary position and condition of an individual or group at the margins of social, political, economic, ecological or biophysical systems, preventing them from access to resources, assets, services, restraining freedom of choice, preventing the development of capabilities, and eventually causing (extreme) poverty (Gatzweiler et al. 2011:3).

The above definition resonates with the experiences of migration into South Africa where African migrants in particular have limited entitlements or access to resources and public services. Based upon Gatzweiler's et al. (2011:9) notion of marginality, South Africa is clustered into what they refer to as 'causal complexes' or 'marginality patterns' - the racial, ethnical and tribal divisions and practices that are still prevalent in society. The work of Bell Hooks (1990) titled Marginality as a site of resistance (1990), provides a unique contribution. As an 
American who experienced segregation, Hooks development of 'a particular way of seeing reality' - as a lens to examine a community like hers. She proposes that it be 'looked both from the outside-in and from the inside-out to focus their attention on the centre as well as the margins of their communities in order to give meaning to their experiences of segregation'. She envisions discrimination and marginality as a site of radical possibility, a space of resistance which is central to creating a counter hegemonic discourse, with the ability to transform the world. Therefore, as she sees it, marginality should not be seen 'as a sign marking the condition of pain and deprivation' but rather, as a position and place of resistance which is crucial for the oppressed, exploited, and colonised people.

Messiou's (2010) work on inclusion, marginalization and education also offers relevant insights insofar as she asserts that marginalisation is not a,

unitary entity but has multiple conceptualisations and articulates four levels of marginalisation, (1) experienced by the individual; (2) experienced by the individual but not recognised by others; (3) the individual is construed by others as belonging to a marginalised population; and (4) experienced by the individual but denied by the individual (Messiou 2012).

In this regard, Joan Mowat (2015: 456) has observed, these categories also raise the important question, 'If an individual does not recognise their life as marginalised (which implies that they do not experience their lives in this way), by what legitimacy can they be considered by others to be marginalised?'-a question which has particular significance for public policy.

In considering these interpretations for the current analysis, this article is mindful of the questions raised by Mowat and will draw on the significance of these categories of marginalisation to apply them within the context of migration in South Africa. Evidence of the lived experiences of migrants in South Africa were documented in a study undertaken by the author in 2015 , which was conducted by way of interview and focus group discussion with migrants in selected protestant congregations around Johannesburg. In responding to a question; 'How do you feel about living in Johannesburg?', '

1 Focus Group Sequence, 29 August 2015. Yoeoville, Johannesburg, from a study conducted towards a PhD. For more details, Mpofu, B. (2015). When the people move, the Church moves: A critical exploration of the interface between 
participants shared their daily interactions with the police and local South Africans citing xenophobia and demand for bribes by the police and Home Affairs officials as some major challenges they endure. As a result, one of the participants proclaimed,

I'm not a fruit that fell from a tree and they must come and eat. I have a father, I have a mother, I have friends, I have a family, I have a country, and I have a home also. So people must not look us like I'm coming from nowhere, I didn't fall from a tree (Focus group participant, 30 Aug 2015)².

To say 'I am not a fruit', implies that the participant felt his human dignity has been undermined in South Africa. This statement reflects frustrations with corruption and also highlights concerns about food security (fruits) for both locals and foreigners who compete for resources. The statement has been used as part of the title for this paper because it profoundly highlights that economic development and struggles that come with it are not just a reserve for local South Africans, all people 'who live in it' share in socio-economic and political gains or losses of the country.

\section{Between Economy and Opportunity: New Biases towards Migrants}

\section{Economy, Electioneering and Development}

During the 2019 national elections in South Africa, migration more than before featured as an issue on party manifestos. In recognition of this worrying trend,

Migration and Theology through a Missiological study of selected congregations within the Uniting Presbyterian Church of Southern Africa in Johannesburg. Unpublished PhD Thesis, University of KwaZulu-Natal S.A.

${ }^{2}$ This was one of the statements from Mike (not his real name) the focus group participant who shared his lived reality as a migrant engaged in public spaces and how he felt unrecognised as human being with a dignity like any South African. The focus group participant drew from the metaphor of a tree and its fruits to express his frustration with corrupt police officers who demand money from migrants every time they see them. 
Sonke Gender Justice, a regional NGO, published a report titled 'Gender and Migration Analysis of 2019 Election Manifestos' in which they analysed manifestos of nine political parties, paying attention to gender issues and assessed the extent to which these manifestos reflected on important policy issues such as female representation, gender equality, issues relating to LGBTIQA and sexual and reproductive health as well as migration. Most notably, the Democratic Alliance (DA) claimed that its plan is to 'secure borders' because 'the impact of porous borders and an ineffective, mostly corrupt Department of Home Affairs (DHA) has created a situation where we are completely unaware of the number of people who come in and out of the country' (Julius 2018).

With respect to migration, opposition parties like the DA also believe it they are '.. the only party which is willing to tackle the challenge [of xenophobia] head on and provide leadership on this difficult and indeed emotive issue'. To do this, their manifesto highlights the need to ensure legal migration into South Africa and effectively policing of borders and rooting out corruption in the immigration processes. According to Sonke Gender Justice (2019), most opposition parties hold the view that tightening control of the country's borders will address the socio-economic problems and xenophobia and the report laments that migrant as well as sex worker rights are not dealt with in a progressive manner or outside the discourse of crime and illegality. Even more striking, manifestos of some political parties such as the Freedom Front Plus blame South Africa's performance and declining socio-economic conditions on the presence of migrants as it states,

South Africa is the recipient of large numbers of illegal immigrants whose potential to contribute to the country has not been assessed. These illegal immigrants put immense pressure on already scarce resources, such as, water, health care, job opportunities and other social services. This is to the detriment of South African taxpayers ${ }^{3}$.

Like the report by Sonke Gener Justice, the South Africa Migration Project (SAMP), in 2012, published a report on the link between food security and

${ }^{3}$ The FF Plus 2019 Manifesto. Available at:

https://www.politicsweb.co.za/news-and-analysis/the-ff-plus-2019-manifesto. (Accessed: 22/05/2019). 


\section{Buhle Mpofu}

migration, to expose some of the assumptions that inform generally anti-migrant sentiments. In the Report, Crush (2012) notes the absence of any systematic discussion on the relationship between population migration and food security, and explores the question of whether migrants are more food insecure than internal migrants (people who move from rural areas to cities for the purpose of work), as well as well as whether there are any differences between migrant and non-migrant households in where they obtain their food in the city. The report noted that,

Migrant households were more likely than non-migrant households to patronise supermarkets. The opposite was true with regard to the informal food economy. The reason for this difference is not immediately apparent but may have to do with the fact that non-migrant households would be more familiar with alternative food sources compared with recent in-migrants, in particular, who would be more likely to know about and recognise supermarket outlets.

The SAMP report reveals that while levels of food insecurity are unacceptably high amongst the poor people in South Africa, migrant households have a greater chance of being food insecure given that they lack social protection and proper documents to access public services, they have no entitlement to anything (Crush 2012).

Ngandu (2010) notes that these reports reveal that although South Africa's performance, shifting policies, declining socio-economic conditions are result of a protracted socio-economic struggle with successive governments attempting to reverse the impact of apartheid since 1994, public and political sentiments nevertheless blame migrants for declining fortunes.

\section{The Radical Economic Transformation (RET) Program and its Precedents}

For many the ANC's policies of radical economic transformation emerged as a mechanism that would circumvent the structures of sustained inequality, and provide the poor with access to social and economic upliftment, as imagined in Mandela's rainbowism. Commenting on RET program, Deon Oberholzer (2018) observed that 'Radical Economic transformation done right is economic inclusion'. While acknowledging that the extremes between poverty and wealth 
require a radical economic paradigm, political and public discourse should be sensitive to the volatility of the South African context and promote peace and stability. In an article that seeks to conceptualise 'radical land reform' Jankielsohn and Duvenhage (2017) examine similar approaches in the People's Republic of China (PRC), the former Union of Soviet Socialist Republics (USSR) and Zimbabwe to draw lessons through comparative analysis indicating that land reform requires a balance between existing land rights and food security on the one hand, and the urgency for historical redress and redistribution on the other and observed that,

A great deal of political rhetoric has been uttered regarding radical economic transformation that includes calls for more radical land reform proposals. This rhetoric is the source of political mobilisation in both the governing African National Congress (ANC), as well as the Economic Freedom Fighters (EFF) opposition. While the ANC call for the end of the willing buyer, willing seller principle in land reform policies and legislation in line with their National Democratic Revolution (NDR), the EFF support a more extreme expropriation without compensation approach. Both these approaches can be regarded as forms of radical land reform that are grounded in their specific ideological orientations (Jankielsohn \& Duvenhage 2017).

Jankielsohn and Duvenhage (2017), further observed that radicals are known to challenge the most established values of society and may differ from one another in fundamental ways. On the one hand there are radicals who postulate the idea, 'I know the good, extend it', while on the other side there are those who postulate, 'I know the evil, eliminate it'. While the former may promote greater involvement in their approach to politics, the latter may promote greater resistance (Stankiewicz 2001:217). Those on the extreme left of the radical spectrum are often referred to as hawks, due to the often-violent methods employed by them, while those on the right of this spectrum are referred to as doves, due to the often-peaceful methods of protest (Stankiewicz 2001). Within the South African context, the use of the term 'radical' provides political justification for leaders who think they 'know good from evil' and therefore consider themselves as liberators of the masses, with little or no consideration on of the implications for such rhetoric on peace and stability Mpofu 2018). 
Therefore, it is not surprising that the RET program has received mixed opinions since it was launched. For example, the Sunday Times ${ }^{4}$ reported that one of South Africa's richest businessman Johann Rupert described the program as ' $a$ code word for theft' to the ire of the political leaders who labelled him a Capitalist. The South African government hit back, tweeting that it 'totally rejects this narrow perception which only seeks to divide our nation' and later issued public statements to assure investors that the land reform program will be conducted lawfully and South Africa will not follow the route taken by Zimbabwe. In this section the intention was to highlight how three areas, namely, economy, development and electioneering reveal an ideological shift not just away from embracing the presence of migrants in Mandela's rainbow nation, but a publicly embraced policy shift against migrants. A closer examination of the RET, Election manifestos, service delivery and other developmental priorities paints a worrying picture about the place of migrants in a democratic South Africa.

\section{Seeking Justice from the Margins - Reimaging the Rainbow Nation}

Despite some of the government achievements such as improved social security through provision of grants, rolling out free education, reducing crime rates in some areas, there still remains a huge gap between the rich and poor. Additionally, the lived experiences of foreign migrants reflect that they have not been integrated or accommodated into the South African communities. As a result, they live on the periphery of society where they experience constant attacks and exclusion from economic activity as scapegoats of the failure of governments' policies. A closer examination of how migrants survive indicate that overall, immigrants are likely to create opportunities for employment ${ }^{5}$.

Drawing on the concept of Hooks Bell, Marginality as a site of resistance (1990), migrants have 'a particular way of seeing reality' or the causal

${ }^{4}$ https://www.timeslive.co.za/sunday-times/business/2017-09-13-radicaleconomic-transformation-is-just-a-code-word-for-theft-rupert/ (Accessed on 13 September 2018.)

${ }^{5}$ See also Raphael Chaskalson, Do immigrants 'steal' jobs in South Africa? What the data tell us. Available at: https://www.groundup.org.za/article/doimmigrants-steal-jobs-south-africa-what-data-tell-us/. [Accessed: 24/05/2019]. 
complexities and patterns of marginality - in their communities. Like Hooks did with her experience of segregation, they look both from the 'outside-in' and from the 'inside-out' to focus their attention on the centre as well as the margins of their communities in order to give meaning to their fear, xenophobic attacks and economic exclusion. This has the following theological implications:

First, the categories of marginalisation, identified my Messiou (2012), are clearly visible within the lived experiences of migrants in South Africa. Dealing with discrimination and targeted violence exposes them to marginality while neglect of their circumstances by political and security leaders expose them to marginality but not recognised by others, especially those in power. For a migrant to say 'I am not a fruit' this reflects their frustrations with the failure of the government to address economic exclusion and corruption which African migrants have to endure in their survival on the margins of society.

Secondly, despite revelations for a shifting rainbowism towards antiimmigrant policies and rhetoric, as reflected in political manifestos, there is no clear program to promote the inclusion of migrants in the South African economic development strategy. Migrants continue to be marginalised while levels of food insecurity are high. Additionally, migrant households face a greater chance of being food insecure given that they lack social protection and documentation to access public services (Crush 2012).

Finally, to focus their attention on the centre as well as the margins, means that migrants understand that they are victims of systemic and unjust economic practices. But given that the marginality they experience as individuals is not recognised by some local South Africans, especially those in leadership, they are disadvantaged by the social constructs of them as the "other" and are seen as belonging to a marginalised (migrant) population even despite their personal circumstances. This disadvantaged position does not stop them from pursuing their goals. Hooks has observed, such discrimination and marginality become 'a site of radical possibility, a space of resistance which is central to creating a counter hegemonic discourse, with the ability to transform the world.' Therefore, as she sees it, marginality should not be seen 'as a sign marking the condition of pain and deprivation' but rather as a position and place of resistance which is crucial for the oppressed, exploited people. Looking at the experience of migration in this way is both transformative and empowering. Transformative in that it can inform policy shifts, and empowering in that local South Africans can also draw on these survival strategies to exercise patience with the government as the country strategically moves to continue redressing 


\section{Buhle Mpofu}

the imbalances of the past. In seeking to rekindle the South African dream, Mamphela Ramphele (2018) drew on Mandela's wisdom and had this to say:

Our daily deeds as ordinary South Africans must produce an actual South African reality that will reinforce humanity's belief in justice, strengthen its confidence in the nobility of the human soul and sustain all our hopes for a glorious life for all [and posed the questions] ... 'do you remember the dream we embraced to build ours into a great society - a prosperous constitutional democracy united in its diversity? Do you remember our commitment to promote human dignity (Ubuntu) and banish humiliation and disrespect of our apartheid past? Do you remember that we agreed that our democracy would be known for being responsive to the social and economic needs of all citizens? Do you remember?'.

\section{Conclusions}

In providing an overview of the migration experience, and policy shifts, this article highlighted that the lived experiences of African migrants in South Africa do not mirror the ideal of a 'rainbow nation.' The article supports the idea that there needs to be a return to the values of the freedom charter and the constitution, which states that South Africa 'belongs to all who live in it'. Given the significance of these ideal principles, there is a need for policy makers to pay more attention to these values in designing and implementation social and economic development programmes. Incorporation of migrants should be at the centre of community building and social cohesion as means to enhance peace and justice between locals South African and foreign migrants. By analysing the political developments beginning with the era of Nelson Mandela's 'rainbow nation', through to Thabo Mbeki's Growth, Employment and Redistribution (GEAR), Zuma's Radical Economic Transformation (RET) and more recently, Cyril Ramaphosa's Thuma mina (Send Me) economic development policies, the paper notes that while initially, Mandela's rainbow nation was inclusive in so far as it dealt with socio-economic inequalities of the past through the Rapid Development Programme (RDP), Mbeki introduced the notion of the developmental state by addressing material inequalities through Growth, Employment and Redistribution (GEAR) and the Black Economic Empowerment (BEE) program presenting an idea that economic upliftment is 
for all. However, under the leadership of Zuma, and with growing allegations of corruption in the government, people got frustrated by the slow transfer of economic wealth, widening gap between the rich and the poor and as a result two things emerged; scapegoating migrants as frustrating local people's access to work and wealth, and proposing of the radical economic transformation (RET) as means to speed up the transfer of wealth from the rich to poor. The paper argues that it is this privileging of South African citizens in the RET programme that saw the ideological shift against migrants and the change in mood from inclusion to marginalization of migrants in the economy.

This article also drew on the notions of marginality to posit that the idea of the creation of a rainbow nation which was envisaged during Mandela's era was intended to incorporate diverse communities that reside in the country but this vision has been eroded by negative sentiments towards migrants. By employing categories of conceptualisations of marginality developed by Messiou (2012) and the concept of 'marginality as a site of resistance' crafted by Bell Hooks (1990) article demonstrates that despite being side-lined through economic policies and divisive political rhetoric which portray migrants as a problem, migrants continue to make enormous contributions in the various sectors of the South African economy and their resilience is proving that 'to be in the margin is to be part of the whole but outside the main body, living on the edge' (Hooks 1990). The article suggests that reimaging South Africa and addressing such marginalisation will require a just and humane approach grounded on the ideals enshrined in the constitution and other international legislative and policy instruments which protect the rights of all humanity, especially the vulnerable such as migrants and refugees.

\section{References}

Adelmann, M. 2004. Quiet Diplomacy: The Reasons behind Mbeki's Zimbabwe Policy. Africa Spectrum 39,2: 249 - 276.

Available at:

www.jstor.org/stable/40175024

Armstrong, D., A.C. Armstrong \& I. Spandagou 2011 Inclusion: By Choice or by Chance? International Journal of Inclusive Education 15,1: 29 - 39. https://doi.org/10.1080/13603116.2010.496192

Bottrell, D. 2007. Resistance, Resilience and Social Identities: Reframing 
'Problem Youth' and the Problem of Schooling. Journal of Youth Studies 10,5: $597-616$.

https://doi.org/10.1080/13676260701602662

Bekker, S. 2015. Violent Xenophobic Episodes in South Africa, 2008 and 2015. AHMR 1,3: 229 - 252.

Billet, L. 1976. The Just Economy: The Moral Basis of the Wealth of Nations. Review of Social Economy, 34,3: 295 - 316.

https://doi.org/10.1080/00346767600000017

Bright, N.G. 2011. 'Non-servile virtuosi' in Insubordinate Spaces: School Disaffection, Refusal and Resistance in a Former English Coalfield. European Educational Research Journal 10,4: 502 - 515.

https://doi.org/10.2304/eerj.2011.10.4.502

Crush, J., S. Ramachandran \& W. Pendleton 2013. Soft Targets: Xenophobia, Public Violence and Changing Attitudes to Migrants in South Africa after May 2008. Cape Town: The Southern African Migration Project (SAMP); Bronwen Dachs Muller.

https://doi.org/10.2307/j.ctvh8r3q1

Crush, J., B. Dodson, V. Williams \& D. Tevera 2017. Harnessing Migration for Inclusive Growth and Development in Southern Africa. Cape Town: SAMP Special Report.

Crush, J. 2012. Migration, Development and Urban Food Security. Urban Food Security Series No. 9 (SAMP). Available at:

http://www.afsun.org/wp-content/uploads/2013/09/AFSUN_9.pdf.

(Accessed on 22 may 2019).

Çaglar A. \& N.G. Schiller 2018. Migrants and City-Making: Dispossession, Displacement and Urban Regeneration. Durham: Duke University Press. https://doi.org/10.1215/9780822372011

Carter-Wall, C. \& G. Whitfield 2012. The Role of Aspirations, Attitudes and Behaviour in Closing the Educational Attainment Gap Round-Up. York: Joseph Rowntree Foundation.

Du Toit, W.C. 2006. The Impact of Knowledge Systems on Human Development in Africa. Pretoria: UNISA.

Gatzweiler, F., H. Baumüller, J. von Braun \& C. Ladenburger 2011. Marginality: Addressing the Root Causes of Extreme Poverty. ZEF Working Paper no 77, Center for Development Research, University of Bonn.

https://doi.org/10.2139/ssrn.2235654 
Gelb, S. 2006. The RDP, GEAR and all that: Reflections 10 Years Later. Transformation 62. Available at:

http://transformationjournal.org.za/wpcontent/uploads/2017/05/T62_Part2.pdf

(Accessed on 23 May 2019.) https://doi.org/10.1353/trn.2007.0004

Goulet, D. 2002. What is a Just Economy in a Globalized World? International Journal of Social Economics 29,1/2: 10 - 25. Available at: https://doi.org/10.1108/03068290210412958.

Greiner, C. \& P. Sakdapolrak 2013. Rural - Urban Migration, Agrarian Change, and the Environment in Kenya: A Critical Review of the Literature. Population and Environment 34: 524 - 553.

https://doi.org/10.1007/s11111-012-0178-0

Griffin, T. 2019. South Africa has an Anti-Immigrant Problem, and it Looks a Lot like America's. Available at:

https://www.buzzfeednews.com/article/tamerragriffin/south-africaelection-xenophobia (Accessed on 22 May 2019.)

Grillo, R. \& B. Riccio 2004. Translocal Development: Italy - Senegal. Population, Space and Place 10,2: 99 - 111. https://doi.org/10.1002/psp.321

Hansen, J.H. 2012. Limits to Inclusion. International Journal of Inclusive Education 16,1: 89 - 98. https://doi.org/10.1080/13603111003671632

Hooks, B. 1990. Marginality as a Site of Resistance. In Ferguson, R., M. Gevers, Trinh T Minh-ha \& C. West (ed.): Out There: Marginalization and Contemporary Cultures. Cambridge, Mass. NY: MIT Press, New Museum of Contemporary Art.

Jacques Julius Democratic Alliance MP. DA's Immigration Plan will Secure our Borders and Stop Illegal Immigration. Available at:

https://www.da.org.za/2018/10/das-immigration-plan-will-secure-ourborders-and-stop-illegal-immigration.

(Accessed on 22 May 2019.)

Jankielsohn, R. \& A. Duvenhage 2017. Radical Land Reform in South Africa. Journal for Contemporary History.

Available at:

https://doi.org/10.18820/24150509/JCH42.v2.1 
Jeffrey, A. 2010. Chasing the Rainbow: South Africa's Move from Mandela to Zuma. Cape Town: The South African Institute of Race Relations (SAIRR). Joburg Mayor Mashaba: Foreigners not the Responsibility of the City. Reported on 24 July 2017. Available at:

http://ewn.co.za/2017/07/24/joburg-mayor-mashaba-foreigners-not-theresponsibility-of-the-city\#.

Levitt, P. \& N. Jaworsky 2007. Transnational Migration Studies: Past Developments and Future Trends. Annual Review of Sociology, 33: 129 156. Available at:

https://doi.org/10.1146/annurev.soc.33.040406.131816

Leary, M.R. 2005. Varieties of Interpersonal Rejection. In Williams, K.D., J.P. Forgas \& W. von Hippel (eds.): Sydney Symposium of Social Psychology

Series. The Social Outcast: Ostracism, Social Exclusion, Rejection, and Bullying. Psychology Press.

Machado, D.L., B.S. Turner \& T.E. Wyller (eds.). 2018. Borderland Religion Ambiguous practices of difference. Hope and Beyond. New York: Routledge.

https://doi.org/10.4324/9781351056946

Mamdani, M. 2001. When Victims Become Killers. Princeton: Princeton University Press.

https://doi.org/10.1515/9781400851720

Manzo, K.A. 1996. Creating Boundaries: The Politics of Race and Nation. Boulder, Colo.: L. Rienner.

Messiou, K. 2012. Collaborating with Children in Exploring Marginalisation: An Approach to Inclusive Education. International Journal of Inclusive Education 16,12: 1311 - 1322.

https://doi.org/10.1080/13603116.2011.572188

Mkhwanazi, W.F. 2017. The Lives and Educational Aspirations of Marginalised Migrant Youth: A Case Study in Johannesburg, South Africa. Unpublished $\mathrm{PhD}$ Thesis university of Free States.

Mowat, J.G. 2010. The Inclusion of Pupils Perceived as Having SEBD: Affordances and Constraints. International Journal of Inclusive Education 14,6: 631 - 648 .

https://doi.org/10.1080/13603110802626599

Mowat, J. 2015. Towards a New Conceptualisation of Marginalisation. European Educational Research Journal 14,5: 454 - 476. https://doi.org/10.1177/1474904115589864 
Mpofu, B. 2015. When the People Move, the Church Moves: A Critical Exploration of the Interface between Migration and Theology through a Missiological Study of Selected Congregations within the Uniting Presbyterian Church of Southern Africa in Johannesburg. Unpublished $\mathrm{PhD}$ Thesis, University of KwaZulu-Natal S.A.

Mpofu, B. \& F. Settler 2017. The Limits of Social Responsibility with Respect to Religion and Migration in South Africa. Journal for the Study of Religion 30, 2: 12 - 31 .

https://doi.org/10.17159/2413-3027/2017/v30n2a1

Mpofu B. (2018). Economic Inclusion: A paradigm shift from the radical economic transformation (RET) in the context of xenophobia in South Africa. Advances in Politics and Economic Vol. 1, No. 2, 2018.

Musonda, A. \& L. Schockeart 2018. South Africa on a Perilous Path to Making Criminals of People on the Move. Mail and Guardian 16 August 2018.

Muschiol, G. 2011. Migrating Nuns - Migrating Liturgy? The Context of Reform in Female Convents of the Late Middle Ages. Paper presented at a conference on Liturgy and Migration; Cultural Contexts from the Upper Room to the Cyberspace. Feb 24-27, Yale Institute of Sacred Music.

Ngandu, S., M. Altman, C. Cross, P. Jacobs, T. Hart \& I. Matshe 2010. The Socio-Economic Impact of the Global Downturn on South Africa: Responses and Policy Implications. Available at:

www.hsrc.ac.za/en/research-outputs/ktree-doc/8268

(Accessed on 24 May 2019).

Phillimore, J. \& L. Goodson 2006. Problem or Opportunity? Asylum Seekers, Refugees, Employment and Social Exclusion in Deprived Urban Areas. Urban Studies 43,10: 1715 - 1736.

Available at:

www.jstor.org/stable/43197399; https://doi.org/10.1080/00420980600838606

Pityana, B. (ed.). 2019. Building Blocks towards an African Century: Essays in Honour of Thabo Mbeki, Former President of the Republic of South Africa. Johannesburg: Real African Publishers.

Razer, M. V.J. Friedman \& B. Warshofsky 2013. Schools as Agents of Social Exclusion and Inclusion. International Journal of Inclusive Education

17,11: 1152 - 1170. https://doi.org/10.1080/13603116.2012.742145

Ramphele, M. 2018. How we can Rekindle the South African Dream. 18 February 2018.

Available at: 
https://www.politicsweb.co.za/party/how-we-can-rekindle-the-southafrican-dream--mamph.

Stankiewicz, W.J. 2001. The Essential Stankiewicz on the Importance of Political Theory. Vancouver: Ronsdale Press.

The FF Plus's 2019 Manifesto.

Available at:

https://www.politicsweb.co.za/news-and-analysis/the-ff-plus-2019manifesto

Twenge, J.M., R.F. Baumeister, D.M. Tice \& T.S. Stucke 2001. If you can’t join them, beat them: Effects of Social Exclusion on Aggressive Behavior. Journal of Personality and Social Psychology 81,6: 1058.

https://doi.org/10.1037/0022-3514.81.6.1058

Waller, L. 2006. Irregular Migration to South Africa during the First Ten Years of Democracy. Cape Town: SAMP Migration Policy brief No. 19.

Williams, K.D. 2007. Ostracism. Annual Review of Psychology 58,1: 425. https://doi.org/10.1146/annurev.psych.58.110405.085641

\section{Internet Sources}

http://www.anc.org.za/sites/default/files/National\%20Policy20Conference\%20

2017\%20Economic\%20Transformation 1.pdf .

http://gestaltconsult.com/radical-

economictransformation/?gclid=EAIaIQobChMI24W_lca13QIVy7HtCh3

6fAZ7EAAYASAAEgJXn_D_Bw.

https://tradingeconomics.com/south-africa/unemployment-rate?continent=asia. https://www.timeslive.co.za/sunday-times/business/2017-09-13-radical-

economic-transformation-is-just-a-code-word-for-theft-rupert/

(Accessed on 13 September 2018.)

https://businesstech.co.za/news/government/266925/government-responds-to-

trumps-land-tweet-as-rand-takes-a-knock/

(Accessed on 13 September 2018.)

www.cnbc.com/2018/06/11/italy-refuses-to-accept-migrant-rescue-ship-in-

standoff-with-malta.html

(Accessed on 30 August 2018.)

https://www.iol.co.za/the-star/news/foreign-nationals-burdening-south-african-

health-system-motsoaledi-18129406.

(Accessed on 24 May 2019.) 
Migration, Xenophobia, Socio-economic Exclusion, and Rainbowism

www.cnbc.com/2018/06/11/italy-refuses-to-accept-migrant-rescue-ship-in-

standoff-with-malta.html

(Accessed on 30 August 2018.)

Buhle Mpofu

Post -Doctoral Research Fellow

School of Religion, Classics and Philosophy

University of KwaZulu-Natal

Email: buhlem202@yahoo.co.uk 